\title{
東ドイッの84年農業価格改革について
}

\author{
谷 江 幸 雄 （岐阜経凧大学）
}

本報告では，まず第 1 に80年代経済戦略とその一環として打ち出された新しい農業集約化路線の 必然性とその内容をみたうえで，第 2 にその路線に沿って実施された 84 年農業価格改革の目的，内容 および成果を確認する。第 3 に，ての84年改革の国民経済に対する影響を集中的に示すすのとして食 料禣助金問題をとりあげてその東ドイッ独自の政策的処理について検討する（報告の主なポイントは 図 1 亿示した)。

\section{80 年代経済戦略よ新しい農業集約化路線}

1. 東ドイツ経済の再生産条件の変化と80年代経済戦略

東ドイッ経済の再生産条件は，80年代に入り，一方で科学・技術の進歩と物質的・技術的基盤の 強化，労働力の熟練構成の高度化，新型コンビナート形成に示される生産と労働の社会化の進展, 他方で対外交易条件の悪化，資源・エネルギー価格の高腆など，大きく变化した。こうした（ポジ ティブな，またネガティブな）再生産条件の変化をふまえて新しい経済戦略一フォンド節約型集 約化路線一がうちだされた。その重点目標は，(1) ME 化など科学技術革新の加速化，(2) 資源・ エネルギーの特別投入消費の低減，（3）新規投資より合理化に重点をおいた投資政策などであった (10重点目標)。

2. 経済システム・工業価格の改革

上の経済戦略をおしすすめるために，79８0年に新型コンビナートへの移行をはかるととあに, 82 84年に計画管理システムと工業価格の改革措固を春施した（農業価格改革もあくまでこうした 経済改革全体の枠内で実施されたすのであった)。

（1）新型コンビナートの形成＼cjkstart従来の工業省—VVB——企業といった 3 環制管理システムから ら工業省——ンビナート (企業) の 2 環制に移行した。新型コンビナートは科学技術の開発・設 計から生産・販売・輸出までの自律的な再生産過程を包括した経風結合体であり, コンビナート独 自の統一的科学技術政策の実施をはかる点にその新しい特徽がある。

（2）計画管理システムの改革 特に83年 2 月の「管理，計画化および経済計算制の改善」に関す る政治局決定により，コンビナート・企業の主要業績評価指導として「純生産高」，「純利潤」の 導入など（「住民のための製品・サービス」，「輸出」をあわせ 4 指標），生産的消費とコス卜の低下 に重点をおいたフォンド節約型集約化路線に適合した計画管理システムの改革が行われた。また 「社会フォンド税 (Beitrag für gesellschaftliche Fond)」の導入(84年〜)はその極めて高 い税率—賃金総額の実に70\%-の点でも，その政策目的の点であ注目に値いする。本税は直接 的には労働力節約の徹底化を目的としたものであるが, 後述するように同年の農業価格改革と密接 に関連して導入されたものと考えられる。

（3）工業価格改革 70 年代後半より資源・エネルギーコストの高騰に対応して工業価格引上げが 系統的に実施されてきた。83年末に発布された工業価格形成原則により，それまでの「業績比例価 
格方式」から「コスト比例方式」(イノベーションと効率化・集約化の刺激にポイント）に移行した。 この際，食料品等生活必需品・サービス価格はあくまで据置かれた。

3. 新しい農業集約化路線と地域農業生産体の形成

国民一人当り農地面積の過小 ( $0.37 \mathrm{ha})$ と50年代の社会主義的工業化に上る農業労㗢力不足のも とで歴史的にあ高い食糧消費需要を充足しなければならないという事情に規定されて，他に先がけ て農業集約化路線か提起された (63年第6回党大会)。60〜70年代には“巨額の農業投資による大型 機械化・化学化を実施し，より少ない労働力で多くの産出高を達成する”という労働力節約型ない しフォンド集約型の集約化が追求された。

しかし，(1) 単なる機械化や化学肥料・農薬・飼料の投入增によって達成される土地生産性・家畜 生産性の增大は80年段階である生産力的・技術的限界に達したとみられるとと, (2) オイルショック の影響による資源・エネルギーコストの高騰のもとで生産物 1 単位当り燃料, 肥料, 飼料, 機械の 償却・修理支出を最小化する必要にせまられたとと，(3) アフガン事件など国際緊張激化のもとで特 に穀物生産の効率化をすすめて国内目給率向上をはかることが重大政治課題の一つになったてとか ら, 従来の集約化路線の転換一フォンド節約型 (省エネ・省資源型)への移行一がはかられるて とになった。80年時点の東ドイッにはかかる転換を可能にする客観的・主体的条件（農工業部門の 高い科学技術集積と労㗢力の教育水準, 耕種 - 音産専阿LPG-VEG の形成之経営間協業体 (KOR), 協業連合体 (KOV)，農工合同体 (AIV) など，地域独自の統一的科学技術政策の実施を可能にする 新しい地域農業生産体の形成等）あまた存在した。(西ドイツなど一部の論者の中には70年代後半の 土地生産性の低下や大型畜産施設建設構想の失敗などから農業の工業化が “中断”され，フォンド 節約化路線への移行が余儀なくされたとする者があるが,一面的な見方といわざるをえない)。

\section{84 年農業価格改革の目的、内容およひ成果}

（本章については先の「大会報告要旨」にかなり詳しく書いたので，見出しだけにとどめる）

1. 改革の理念・目的

（1）“事実上の国民経斎的支出”に照応した農産物価格の形成

(2)（1)により農業経営の業績評価や国民所得にたいする農業の奇与の評価を正確に行う

(3) LPG, VEG の再生産力の強化

(4) 農業生産の業績向上への関心づけ

（5）農業生産の生産的消費とコストの低隇への刺減

2. 改革の主要内要

(1)，農業用生産手段にたいする価格差補給金の廃止

(2) 農産物買付価格の大幅引上げ

(特徵)

1. 社会主義農業制度確立以来最大の価格引上げ ( “相対的最劣等地”での生産費を基準に, 引 上げられた生座手段のコスト移転分をカバーし，さらに高い収益性を保障する水準に引上げ られたため)

․ 農産物間・部門間の価格関係の調整

八. 品質に応じた価格格差づけの強化

二. 食料品の小売価格を据置きにして買付価格引上げを実施 
(3) 農業税制の改正

（特徵）買付価格引上げによって增大した差額地代部分の国庫集中を意図したもの

1. 定額納付金による差額地代 I の収用

口. 立地関連補助金

八. 利潤関連納付金

（4）農業奖励金その他の経済的措置の改正

3. 改革の成果之問題点

(成果)

（1）史上最高産出高 (84 86年) 達成への寄与

(2) 生産的消費とコストの大幅低下の達成

(3) 経営収益性の顕著な改善

(4) 農産物の品質向上

（5）個人副業経営への生産刺激効果（東ドイツにはソ連邦のバザールのような自由市場はなく，個 人経営の生産物は社会化経営のそれと同樣に一若干低い価格で——買付けられる) (問題点)

（1）“事実上の国民経済的支出に照応した価格”形成の不徹底（生産手段補助金廃止の不徹底，価 格計算における労働力再生産費・減価償却費算入の不十分さ）

(2) 差額地代の分配問題

（3）食料補助金の急増

\section{84 年農業価格改革の国民経済にたいする影響 一一食料補助金問題の政策的処理を 中心に}

1. 食料補助金を除く直接的農業関係予算収支バランスへの影響については，価格庁長官 W 。ハルプ リッテルの指摘のごとく「84年にはじめて農業からの国家財政収入がその支出を上回（第 1 表の費 目(4): (9))り，85年す収支トントンとなった。てれは“補助金農政”からの脱却，農業の自立化を めざす方向を示すすのとしてそれなりに評価されよう。

2. しかし，食料補助金を含めた広義の農業関係予算収支バランス（同表の(4)：(11)）をみると，支出 超過額が—-84年こそ農業税の增亡生産手段補助金の減により減少したものの一 85 年以後著しく 增大している。食料補助金の歳出にしめる比率は14\%（86年）とソ連邦の場合とほぼ同水準にも達 した。

3. これはハンガリーなどかなりの東欧諸国（ソ連邦でも食料価格引上げ論が強まっている）が80年 代に入り食料価格を引上げているあとで，東ドイッは今回の農産物価格の大幅引上げにさいしても あくまでその小売価格安定化政策を“死守”しようとしているととの必然的な結果である。その背 景としては，さまざまなてとが考えられるが，食料品等生活必需品価格安定化が西ドイッにたいす る強烈な対抗意識から社会主義経済の優位性を示す最重要指標の一つとみなされていることが考え られる。それ沛え，近い将来ソ連邦が食料引上げに踏切ったとしても東ドイッがそれに追随するて とはないであろう。

4. それでは東ドイッの政策当局はかかる食料補助金問題をどのように処理しようとしたのか。結論 的にいえば，工業コンビナート・企業にたいする新税すなわち前述の賃金コストに課せられる「社 
会フォンド税」の導入 (84年 1 月 1 日〜) で食料補助金等生活必需品価格支持の増大のための巨額 の恒久的財源を確保しようとしたのではないか, というのが私の“仮説”である。社会フォンド税 導入の直接の目的が工業部門における労働力節約化・合理的利用にあったてとはいうまでもないが, 農産物価格と賃金コストの理論的連関や農業価格改革と社会フォンド税導入の時期的一致からして, また第 2 表にみられるように金額上の対応加らしても，両者がワンセットのかたちで実施されたて とはあきらかであろう。また，社会フォンド税の税率 (70\%) やその税収総額の規模 (85年に266 億マルク，歳入の11.3\%）からして，乙れは東ドイッの高度の工業力体系をふまえてはじめて可能 になった政策選択だといえよう。

\section{〔参考文献〕}

詳細はつぎの拙稿を参照されたい。

1. 谷江幸雄「ドイツ民主共和国 (DDR) におりる農業の集約化と農産物価格政策 (1) (2)」『岐阜経 済大学論集』第20巻第 4 号 (87年 3 月)，第 21 巻第 1 号 (87年6月)。

2. 谷江幸雄「ドイッ民主共和国（DDR）農業に拈ける固定生産フォンドの再生産と物質的・技術的 基盤の強化」，同，第19巻第 4 号 (85年10月)。

3. 谷江幸雄「東ドイッの84年農業価格改革について」, 第27回社会主義経済学会『報告要旨』 (87年6月)。 


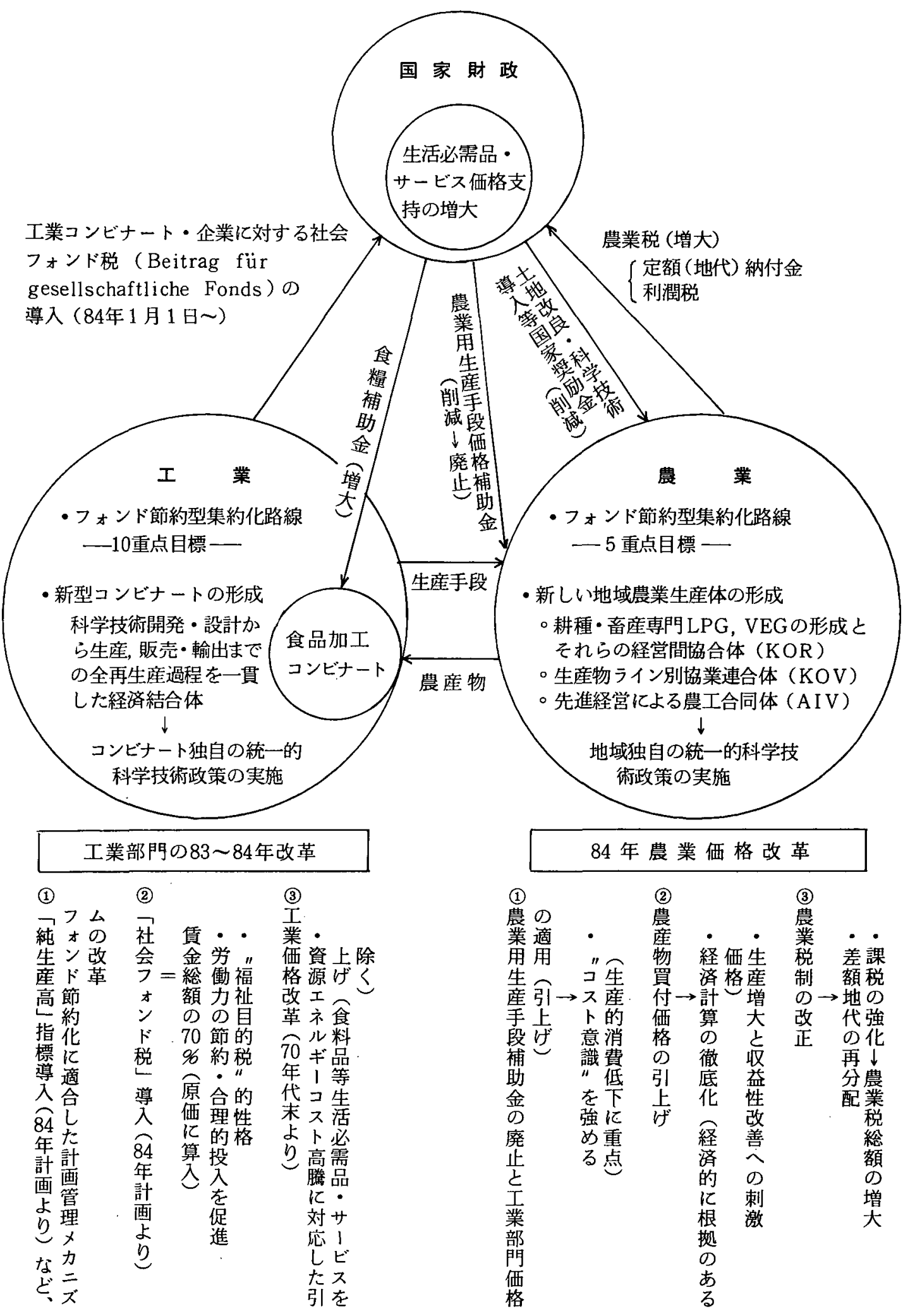


図 2、生産物単位当り平均買付価格指数の推移（耕種作物；1970年=100）

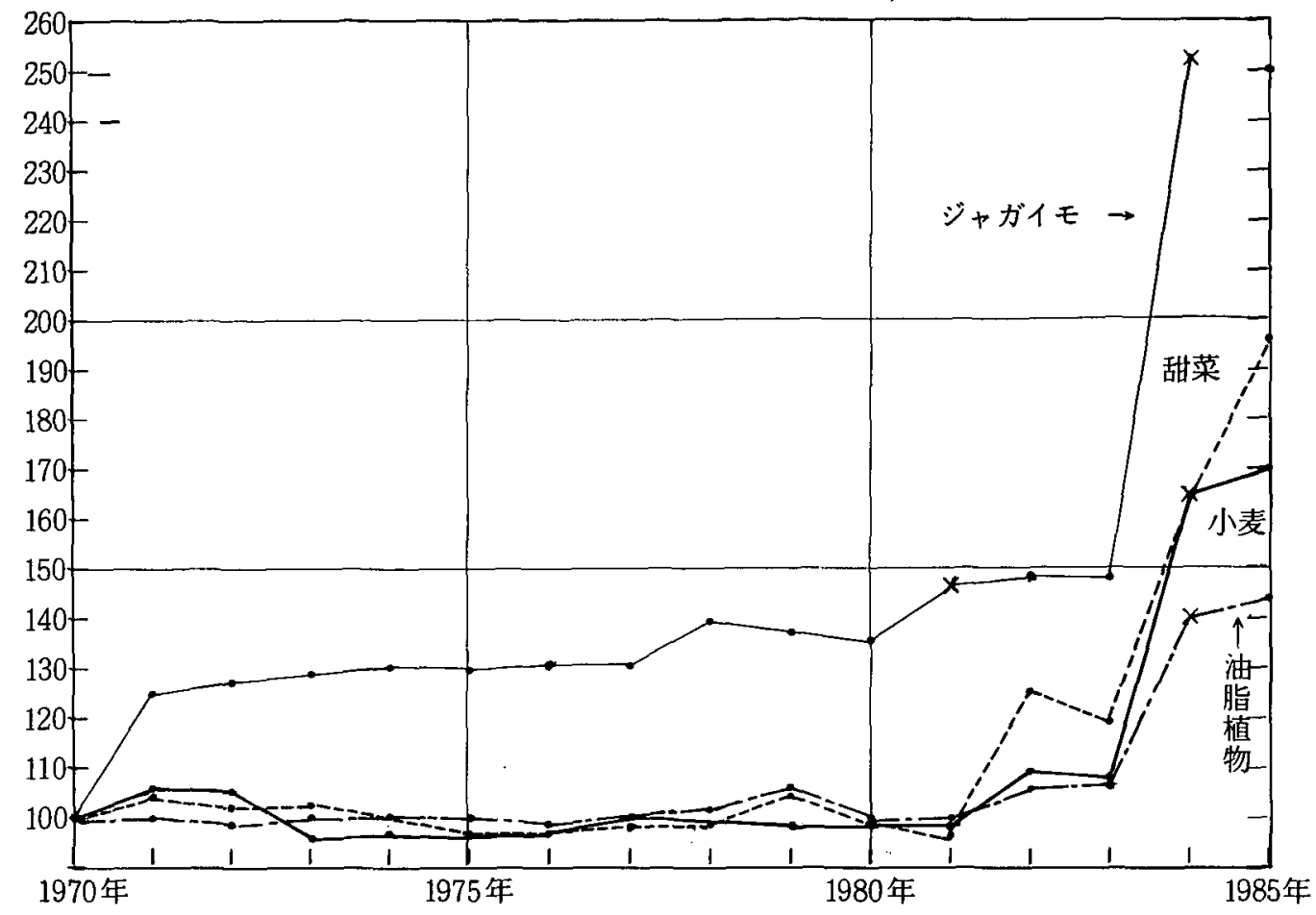

（注） $\times$ 印は基本買付価格の改定を示す。

図 3. 生産物単位当り平均買付価格指数の推移（玄産物；1970年 $=100 ）$

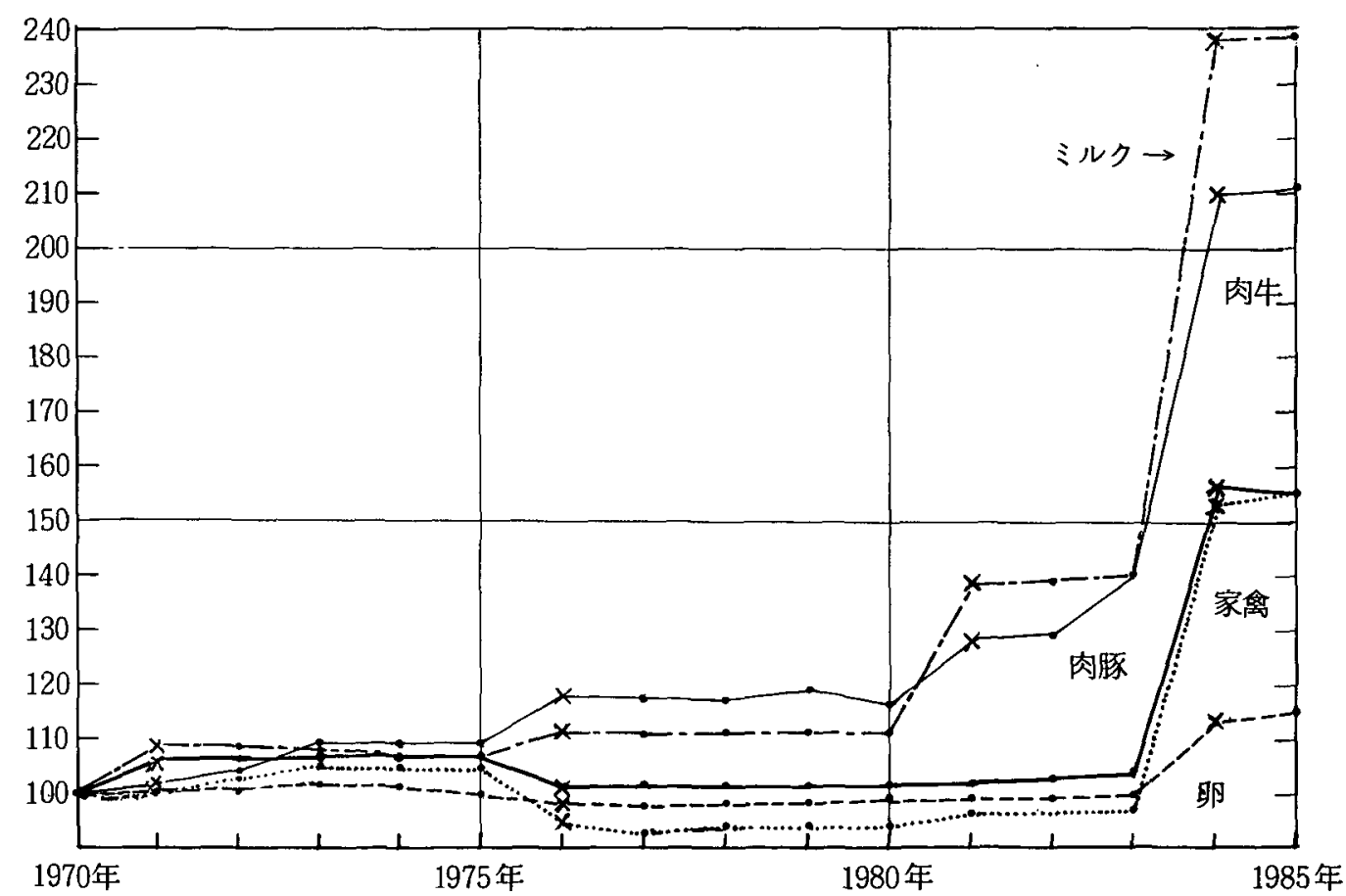

（注） $\times$ 印は基本買付価格の改定を示す。 
表 1. 農農業関係予算の収支バランス

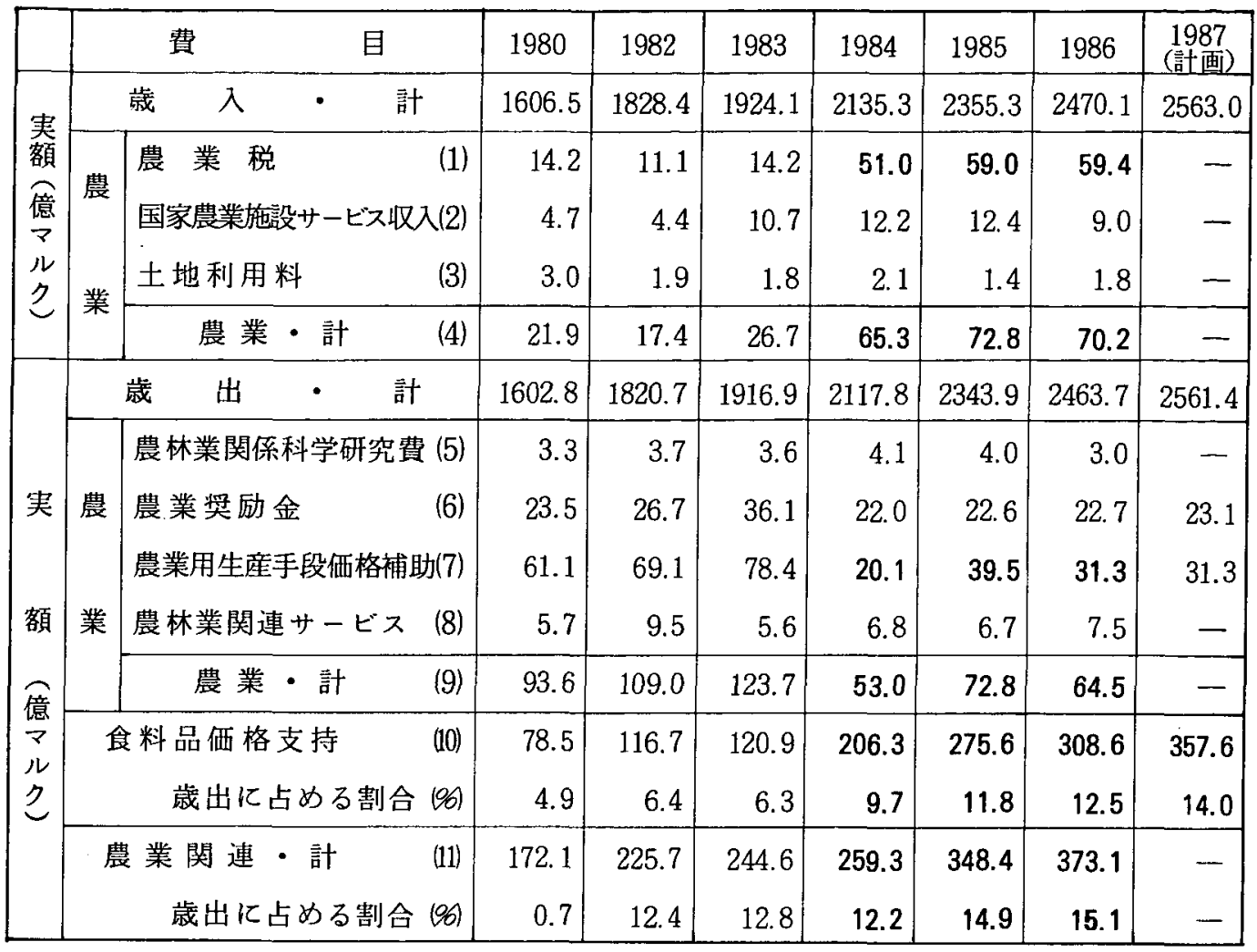

表 2. 食料品等生活必需品・サービス価格支持と社会フォンド税の相関

\begin{tabular}{|c|c|c|c|c|}
\hline & 1983 & 1984 & 1985 & 1986 \\
\hline 生活必需品・サービス価格支持 & 218.5 & 318.2 & 406.2 & 478.8 \\
そのうち食料補助金 & 120.9 & 206.3 & 275.6 & 308.6 \\
\hline 社会フォンド税 & & 200.9 & 266.0 & 339.7 \\
\hline
\end{tabular}

